Simposium I Jaringan Perguruan Tinggi untuk Pembangunan Infrastruktur Indonesia, 2016

\title{
Assessment to Low-cost Apartment in Sidoarjo District, East Java Province
}

\author{
Ria A.A. Soemitro ${ }^{1}$, Farida Rachmawati ${ }^{2}$ \\ 1,2 Civil Engineering Department, Institut Teknologi Sepuluh Nopember \\ Kampus ITS Sukolilo Surabaya - Indonesia 60111 \\ Email: farida.rachmawati@gmail.com; soemitroraa@gmail.com
}

\begin{abstract}
The low-cost apartment development program is one of the reliable solutions to reduce housing backlog in East Java Province due to land scarcity and high price of land. There are some supporting regulations concerning low-cost apartment management and implementation. But in some aspects, the regulation is not applicable. The objectives of this research are to compare the low-cost apartment regulation and real implementation in Sidoarjo and to generate improvement strategies. The regulation and technical standard variables were obtained from literature review studies. The comparison parameters to better understand the low-cost apartment implementation were then observed to purposive sampling respondents from management team and 60 random sampling respondents from inhabitants. These unconformity variables were then identified and analyzed using descriptive statistic. The result shows that some problems between regulation and real implementation are associated with rental price, inhabitant segmentation, maintenance program. Some strategies for the better implementation according to the inhabitant's need and regulation are determine segmentation and limitation in rental period, scheduling the operation and maintenance periodically and list it in the planned cash flow, consider to create spesific institution to operate the low-cost apartment in order to overcome the finance system constraint and adjust more proper rental price.
\end{abstract}

\section{Introduction}

The high population density due to the growth of industry sector has brought some problems related settlement provision. The industrial sectors play the important roles in housing provision problem since almost half of the industrial employees who come from the districts all over East Java Province, live in the suburbs or in greater Surabaya (>10 km) with lower housing price and it may triggers high transportation cost [1]. The low-income employees tend to live in the illegal slump area close to the workplace to reduce high transportation cost. On the contrary the growth of housing is not equal with the needs and resulted in the growth of illegal housing in the illegal slump area. One of problems facing the settlement provision is housing backlog rate in Indonesia, East Java Province and especially Surabaya. Until 2012, the housing backlog is 600.000 units [2]. On the other hand, only 60.000-70.000 units per year could be provided by the East-Java Province Government and private sector. The housing backlog rate was also caused by the land scarcity and the housing expensive price [1].

In Indonesia, low-cost apartment development program is one of Government's solutions to reduce housing backlog which dedicated for low-income people [3]. The existing low-cost apartments were always built by the Ministry of Public Works and the Ministry of Public Housing. Until 2014, local Government in East Java Province (Province, Municipal and District) has adopted this program by developing 276 twin blocks include 21,644 units [4].

Sidoarjo District Government, which is part of Surabaya Metropolitan Area, also manages 5 (five) granted low-cost apartments. In order to support the operational maintenance program, there are some regulations concerning low-cost apartment management, implementation and organization. Unfortunately, in some aspects, existing low-cost apartment implementation do not meet the regulation and inhabitant's need. The objective of this paper are to compare the low-cost apartment regulation and to describe real implementation in Sidoarjo District Government.

\section{Study Location}

Surabaya Metropolitan Area consists of 3 (three) municipal and districts, namely Surabaya Municipality, Gresik Districs and Sidoarjo Districts. Sidoarjo District has 2744 people/km2. There are 5 low-cost apartments managed by local government in Sidoarjo. 2 low-cost apartment, named Ngelom and Bulusidokare, will be investigated in this paper. Bulusidokare has more proper facilities but only 1 of 3 twin blocks have been already occupied. In contrast, Ngelom which is almost full occupied, has improper facilities.

\section{Literature Review}

3.1. Government Regulations

a. Indonesian Republic Act no 20/2011 concerning low-cost apartment

- The objective of low-cost apartment development program is to fulfill the social and economic needs through affordable and adequate settlement especially for low-income group (article 3).

* Corresponding author.

E-mail address: farida.rachmawati@gmail.com; soemitroraa@gmail.com 
- The development planning concerning location should follow the municipal/district government spatial regulation (article 13)

b. Indonesian Housing Minister Regulation no 14/2007 concerning low-cost apartment management

- Inhabitant which mentioned the inhabitant categories are government employee, army/police, labours, low-income group and strudents (article 15)

Inhabitant responsibilities (article 20):

1. Pay the rental fee monthly

2. Keep the building cleanliness

3. Pay the utilities retribution

While inhabitant prohibitions are:

1. Illegal take over of the unit

2. Over capacity unit occupation (article 21)

c. Indonesian Housing Minister Regulation no 18/2007 concerning low-cost apartment tariff

There are 3 types of rental price (article 6):

1. Commercial rental price is rental price determination based on the sum of the overall investment costs by considering the value of depreciation over the economic life of the building, the interest rates, monthly maintenance and operating costs, divided by the number of low-cost apartment unit.

2. Base rental price is rental price determination based on the monthly maintenance and operations cost divided by the number of low-cost apartment unit.

3. Social rental rates is rental price determination based on the monthly maintenance cost divided by the number of low-cost apartment unit.

d. Indonesian Minister of Public Works Regulation no 05/PRT/M/2007 concerning technical standards of high-rise lowcost apartment

e. Indonesian Minister of Public Works Regulation no 29/PRT/M/2006 concerning technical standards of high-rise building

\subsection{Comparison Criterias}

According to the Indonesian Act no 20/2011, the low-cost apartment development should follow these aspects:
a. Planning and development
b. Management
c. Occupancy
d. Facilities

This paper will focus on the management aspect regarding inhabitant, tariff and institution.

\section{Data Collection}

To elicit useful data, an empirical questionnaire survey and observation were undertaken in existing low-cost apartment in Sidoarjo. The criterias from Indonesian Act no 20/2011 were adopted to be comparison criterias. In this study, the target survey respondents of the questionnaire included all management bureau from the public sector.

Target respondents were those with direct hands-on involvement in low-cost apartment projects. These respondents were requested to answer the question and describe the real condition. Observation was done to 2 out of 5 low-cost apartments which have been operated and managed by local government (not managed by university or foundation) in Sidoarjo. As Ngelom and Bulusidokare are not full occupied and have some poor building component, so they need to be investigated. There are 384 units and 229 units in Ngelom and Bulusidokare respectively. The respondents was 10\% for each low-cost apartment.

\section{Analysis and Discussion}

\subsection{Management}

Ngelom low-cost apartment, which is operated by Sidoarjo District Government, was built by fund sharing between Ministry of Public Housing (IDR 24 Billion) and Sidoarjo District Government (IDR 2 billion) on 2010. It has 4 twin blocks equipped with parking area, management office, praying place, balcony and other supporting facilities and utilities. While Bulusidokare low-cost apartment was built on 2010 by Ministry of Public Housing, then is operated by Sidoarjo District Government. One of three twin blocks has been occupied since 2010. One twinblocks has 96 units. Trading booth, management office and other public facilities are built surrounding the low-cost apartment. Both Ngelom and Bulusidokare are operated under the institution called Technical Management Unit on Public Works Department, Sidoarjo District Government. The Government allocates IDR 1.2 Billion for officer salary and operational maintenance activities.

Ministry of Housing and Ministry of Public Works are responsible for the low-cost apartment development which would be 
built in the Local Government's land [5][6]. Local Government has operated low-cost apartment after delivery process from Ministry of Housing or Ministry of Public Works [5]. The finance system applied makes the operational maintenance cashflow unflexible as the technical operation unit does not have authority for any programs. Due to long delivery process and poor building quality, Local Government sometimes needs to repair some broken components significantly before operate the lowcost apartment (preliminary survey, 2014). This kind of problem has been occured in all low-cost apartments.

\subsection{Tariff}

Low-cost apartment management includes operational and maintenance activities ([6] article 56 and 57). Operational and maintenance cost are covered by inhabitants in the form of rental fee and government subsidy. That is why according to [7] concerning Guidelines for State-financed Low-cost apartment rental price, there are 3 types of rental price explained in the section 2.

Based on local government regulation [7] and [8], Low-cost apartment operated by Sidoarjo District have lower rental price than low-cost apartment regulation. That is the reason why Surabaya Government always subsidies the operational maintenance cost monthly. In reality, the rental prices are very low and below the social rental price. The rental price for low-cost apartment managed by local government (municipality and district) is between IDR 200.000 - 300.000. Moreover, the operational and maintenance costs have to be subsidized by the province and the local government [5]. Table 1 represents the low-cost apartment tariff in Ngelom and Bulusidokare low-cost apartments, while table 2 depicts the comparison among applied tariff, regulation and planned tariff based on regulation.

Table 1. Existing Low-cost Apartment Rental Price

\begin{tabular}{|l|c|c|}
\hline & $\begin{array}{c}\text { Tariff in Ngelom } \\
\text { Low-cost Apartment (IDR/month) }\end{array}$ & $\begin{array}{c}\text { Tariff in Bulusidokare } \\
\text { Low-cost Apartment (IDR/month) }\end{array}$ \\
\hline 1st floor & 275.000 & 270.000 \\
\hline 2nd floor & 250.000 & 270.000 \\
\hline 3rd floor & 225.000 & 245.000 \\
\hline 4th floor & 200.000 & 220.000 \\
\hline 5th floor & & 195.000 \\
\hline
\end{tabular}

Source: pilot survey, $2014 ;[8] ;[9]$

Low-cost apartment rental price criteria must be affordable to the low-income group which rental price is less than one-third of the income. The low-income group has maximum monthly income IDR 3.500.000 [10]. While the regional minimum salary declared by East-Java Province Governor are as follows:

Table 2. Regional Minimum Salary

\begin{tabular}{|l|l|}
\hline \multicolumn{1}{|c|}{ Municipal/District } & \multicolumn{1}{c|}{ Minimum salary (IDR) } \\
\hline Surabaya & $2.710 .000,00$ \\
\hline Gresik & $2.707 .000,00$ \\
\hline Sidoarjo & $2.705 .000,00$ \\
\hline
\end{tabular}

Source: [9]

Table 3. Tariff comparison

\begin{tabular}{|c|c|c|c|}
\hline & Low-cost apartment tariff & Actual Take home pay & Planned tariff \\
\hline 1st floor & $250000-300000$ & $500000-1000000$ & 333333,3333 \\
\hline 2nd floor & $200000-250000$ & $500000-1000000$ & 333333,3333 \\
\hline 3rd floor & $100000-200000$ & $500000-1000000$ & 333333,3333 \\
\hline 4th floor & $100000-200000$ & $500000-1000000$ & 333333,3333 \\
\hline
\end{tabular}

The range of existing low-cost apartment rental price in Sidoarjo is IDR 275.000 - 350.000. To implement ideal base rental price, it needs Government subsidy or private sectors involvement, who have interested in housing providing for their employees. The ideal rental price will be more realistic when inhabitant segmentation is defined, for example low-cost apartment for government officer or industrial employee to avoid the unpaid monthly rental price.

\subsection{Inhabitant}

5.3.1. Education background

Most inhabitant in 2 low-cost apartments are senior high school graduation, as described in the chart below 


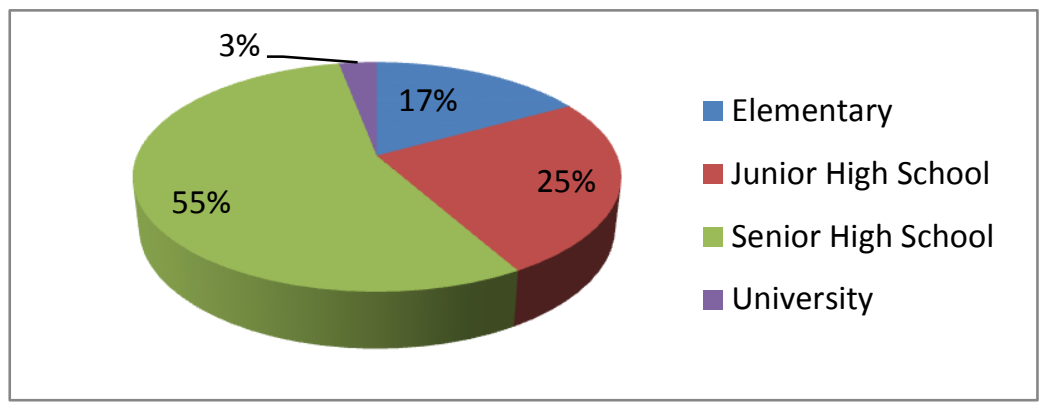

Figure 1. Inhabitant's education

\subsubsection{The inhabitant's origin}

Low-cost apartment development program is aimed to fulfill the proper housing needs, especially for low-income people ((7) article 54) and for migration communities. Some existing low-cost apartments in Sidoarjo are occupied by mixed segmentation, not only low-income people but also moderate income. The low-cost apartment's inhabitants are from relocation program communities and re-settlement program. Most of them are coming from outside Sidoarjo.

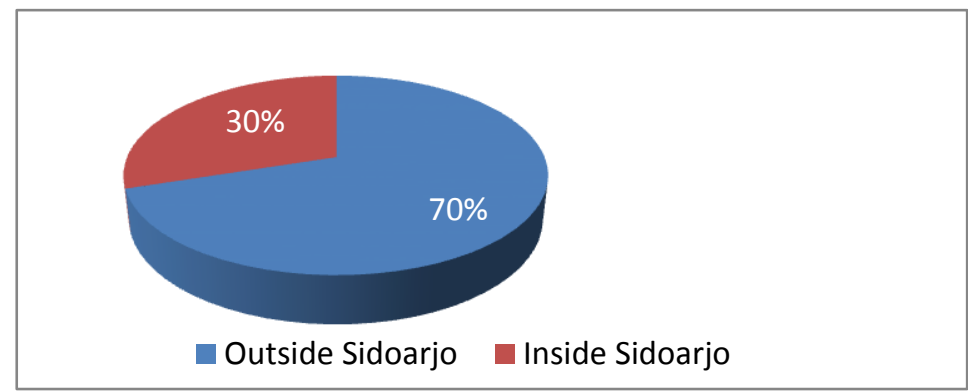

Fig. 2. Inhabitant's origin

\subsubsection{Length of stay}

According to the regulation, the length of stay for inhabitant is 3 years, and it may be extended twice [9]. In fact, the inhabitants have been occupied for more than 3 years as described in the figure.

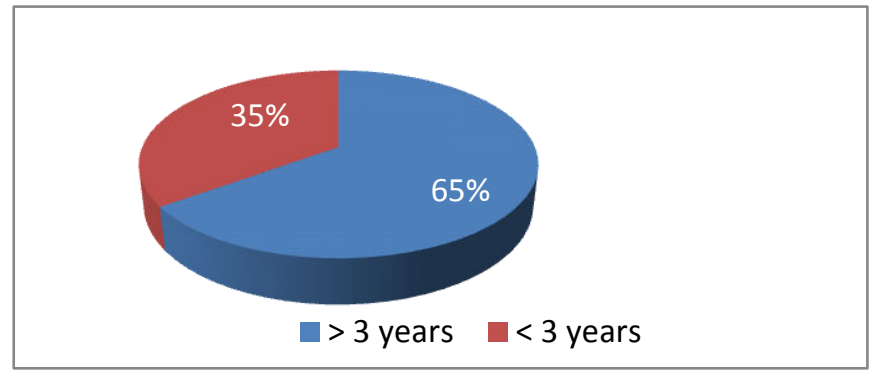

Fig. 3. Length of stay

\subsubsection{Inhabitant's occupation}

Low-cost apartment development program is aimed to fulfill the proper housing needs, especially for low-income people ((7) article 54). Some existing low-cost apartments in Surabaya are occupied by mixed segmentation, not only low-income people but also moderate income and even unemployed. There is no segment and special low-cost apartment, for instance low cost apartment for industrial employees or other certain institution employee. Their occupation is closely related to the responsibility and ability to pay the rental fee monthly. Sidoarjo government has tried to select the inhabitants by their occupation as described in the chart below. 


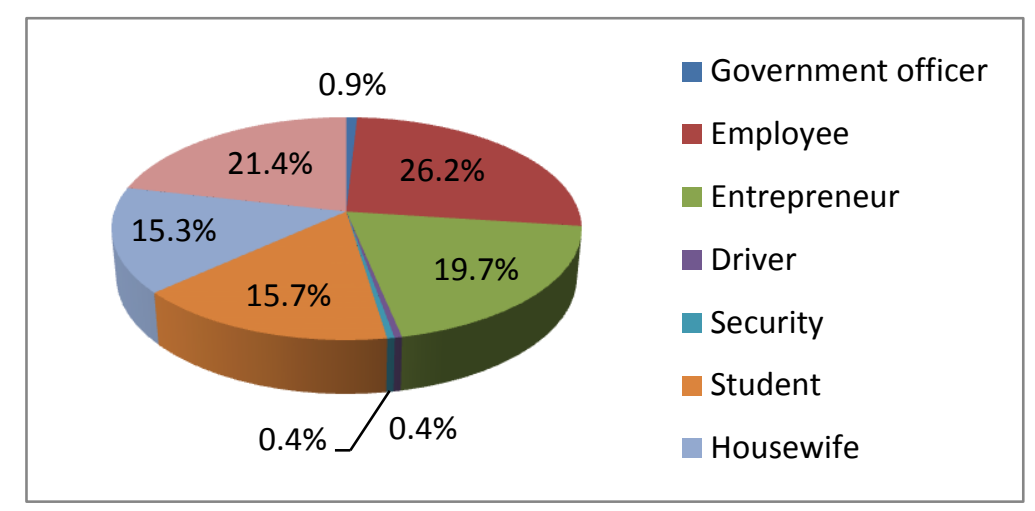

Fig. 4. Inhabitant's occupation

\section{Improvement strategies}

Learning from the past experience on developing low cost apartment, five essential suggestions are carried out to attract more developments in the future.

- $\quad$ Segmented inhabitant to ensure the inhabitant rental payment and proper rental price

For example low-cost apartment development for industrial or certain institution

- $\quad$ Limitation in rental period

The penalty should be adopted by management body for the extended occupancy and illegal development

- $\quad$ Arrange the operation and maintenance periodically and list it in the planned cash flow

- Consider to create spesific institution to operate the low-cost apartment in order to overcome the finance regulation constraint.

- $\quad$ Adjusted rental price

The proper rental price should be determined to cover operational and maintenance cost based on real cost and inhabitant's ability to pay

\section{Conclusion}

This paper compares the characteristics of existing low-cost apartment program implementation and regulations using case study approach. Learning from this problem allows making a recommendation on application of similar planning in other sites.

The rental price, period of stay, institutional, occupancy and technical standard have been named as main barriers on repeating this model in other location. But the program should be continued.

Learning from the low cost apartment case study in Sidoarjo, five essential recommendations are suggested for better development in the future. Firstly, determine segmentation. Secondly, determine limitation in rental period. Thirdly, scheduling the operation and maintenance periodically and list it in the planned cash flow. Forthly consider to create spesific institution to operate the low-cost apartment in order to overcome the finance system constraint and finally,adjust more proper rental price. This paper recommends further research on rental price adjustment to obtain better implementation.

\section{References}

[1] R. A. A. Soemitro and F. Rahmawati, "Penyusunan Action Plan Kebijakan dan Program Pengembangan Perumahan dan Pemberdayaan Komunitas Perumahan Jawa Timur (Action Plan Study of Policy and Housing Development Program and Housing Community Empowering in East Java)," 2011.

[2] East Java Province Body of Planning and Development, "East Java Province Body of Planning and Development," 2011.

[3] C. Susilawati and S. Yakobus, "New affordable strata the housing solutions : a case study in Surabaya, Indonesia.," Proc. 2010 Int. Conf. Constr. Real Estate Manag., 2010.

[4] East Java Province Body of Planning and Development, "East Java Province Body of Planning and Development," 2014.

[5] Ministry of Public Works, "Low-Cost Apartment Book, Indonesian Ministry of Public Works," 2012.

[6] Indonesian Ministry of Housing, "Low-cost Apartment and Affordable Housing," 2011.

[7] Minister of Housing, "Regulation no 18/Permen/M/2007 concerning the guidance to determine rental price for state financed low-cost apartment," 2007.

[8] Head of Sidoarjo, "District no 8/2012 concerning Low-cost Apartment rental price in Sidoarjo," 2012.

[9] Governor of East Java Province, "Regulation no 36/2011 concerning Low-cost Apartment Management Guidelines," 2011.

[10] Indonesian Ministry of Housing, "Regulation no 28/Permen/M/2012 concerning Housing provision guidelines," 2012. 
Use the "Insert Citation" button to add citations to this document.

[11] Statistic Bureau-East Java Province, 2013, www.jatim.bps.go.id

[12] Major of Surabaya Regulation no 30/2013 concerning Low-cost Apartment Services

[13] Governor of East Java Province Regulation no 72/2014 concerning Regional Minimum Salary 